Journal of Social Sciences 7 (2): 186-189, 2011

ISSN 1549-3652

(C) 2010 Science Publications

\title{
Suitable Assimilation Model of Culture, Beliefs and Rites Concerning Deities of Buddhism and Hindu-Brahmanism for Peace of Thai Society in Bangkok and Circumferences
}

\author{
${ }^{1}$ Phra Maha Kriangkrai Kaewchaiya, ${ }^{2}$ Suoneth Photisan and ${ }^{3}$ Makhawin Purisuttamo \\ The Research Institute of Northeastern Arts and Culture, \\ Mahasarakham University, Maha Sarakham, 44000 Thailand
}

\begin{abstract}
Problem statement: At present, Thai society widely assimilates culture, beliefs and rites concerning deities of Buddhism and Hindu-Brahmanism by worshipping the deity images at the temples or the abodes of gods in Bangkok and circumferences. A typical worship is to pray the deity for help. As a matter of fact, people should help themselves first and use a prayer as willpower. The purpose of this research were these; (1) to investigate the background of culture, belief and rites concerning deities of Buddhism and Hindu-Brahmanism in Bangkok and circumferences, (2) to investigate the current situations of the assimilation of culture, beliefs and rites concerning deities of Buddhism and Hindu-Brahmanism in Bangkok and circumferences and (3) to determine a suitable assimilation model of culture beliefs and rite concerning deities of Buddhism and Hindu-Brahmanism for peace of Thai society in Bangkok and circumferences. Approach: A qualitative research was used for this research. Research areas were these: (1) Yannawa Temple, Yannawa sub district, Sathon district, Bangkok, (2) Lum Charoen Satta Temple, Yannawa sub district, Sathon district, Bangkok, (3) Brahma House at the Erawan Hotel, Lum Phini sub district, Pathumwan district , Bangkok, (4) Phai Lom Temple, Phra Pathom Chedi, Muang district, Nakhon Pathom Province, (5) Sisa Thong Temple, Sisa Thong sub district, Nakhon Chaisi, Nakhon Pathom Province, (6) Phra Sri Maha Uma Thewi Temple, Silom sub district, Bangkok district, Bangkok, (7) Visanu temple, Thung Wat Don sub district, Sathon district, Bangkok, (8) Thep Nimit Temple, Khok Phaed sub district, Nong Chok district, Bangkok, (9) Brahman Temple, Sao Chingcha sub district, Phra Nakhon district, Bangkok and (10) Ganesha House at Ratchada crossroads, Huay Khwang district, Bangkok. Deity worships have been held at these areas for a long time and a lot of people have participated in these worships. A population was the people who lived in 9 districts. A sample was selected by means of a purposive sampling, consisted of 16 key informants, 64 casual informants and 20 general informants. Research instruments were a survey, an observation, an interview, a focus group interview and a workshop. Research data were examined by means of a triangulation technique. Research results were presented by means of a descriptive analysis. Results: (1) Ancient-Thai society believed in deities and supernatural power so culture, beliefs and rites concerning deities have been handed down from generation to generation (2) At present, Thai people in research areas assimilate beliefs in Buddhist deities and Hindu-Brahman deities together, they worship both Buddhist and HinduBrahman deities; for example Bodhisattva, Ganesha, Brahma and Vishnu (3) A suitable assimilation model of culture, beliefs and rites concerning deities of Buddhism and HinduBrahmanism should consist of faith and wisdom by using beliefs and rites as the reinforcement of life and applying deity's virtue such as a virtue of do not make a sin throughout lifetime in order to enhance peace in society. Conclusion/Recommendation: Research result revealed a suitable assimilation model of culture, beliefs and rites concerning deities of Buddhism and HinduBrahmanism for Peace of Thai society in Bangkok and circumferences. This model can apply to enhance peace for other critical areas in Thailand.
\end{abstract}

Key words: Model of temple, learning centers, eastern region, research findings, developing virtue, appropriate service, community surrounding, creating equilibrium

Corresponding Author: Phra Maha Kriangkrai Kaewchaiya, The Research Institute of Northeastern Arts and Culture, Mahasarakham University, Maha Sarakham, 44000 Thailand 


\section{INTRODUCTION}

Culture is essential for humans because it is a collective consciousness of each society, it includes beliefs, knowledge, languages, art, customs and traditions. The culture of each society results from the way of life of people which they learnt from nature, other societies and accumulated their experience for adapting, transmitting and changing according to the changes of situations so it is dynamic (Talang, 1993). This is congruent with the concept of Kanchana Kaewthep (1982), she writes that culture is the way and the pattern of life of people in each community which has been accumulated and practiced for a long time, it includes knowledge which people have created, determined and maintained from generation to generation, culture forms itself into knowledge, practice, beliefs and manmade-objects. Phraya Anuman Ratchathon (1988) writes about it that culture divides into 2 types are these: (1) material culture and (2) spiritual culture. Material culture relate to physical needs which enhance a quality of life; for example the four requisites of life, vehicles, utensils and weapons. Spiritual culture relate to the things which encourage intellectual and spiritual growth; for example education, religions, ethics, art, literature, laws and customs

Purposes and objectives: (1) to investigate the background of culture, beliefs and rite concerning deities of Buddhism and Hindu-Brahmanism in Bangkok and circumferences (2) to investigate the current situations of assimilation culture, beliefs and rites concerning deities of Buddhism and HinduBrahmanism in Bangkok and circumferences (3) to determine a suitable assimilation model of culture, beliefs and rites concerning deities of Buddhism and Hindu-Brahmanism for peace of Thai society in Bangkok and circumference.

\section{MATERIALS AND METHODS}

Population and sample: A population was the people who lived in 9 districts. A sample was selected by means of a purposive sampling, consisted of 16 key informants, 64 casual informants and 20 general informants.

Instruments: Research instruments were a survey, an observation, an interview, a focus group interview and a workshop.

Data analysis: Research data were examined by means of a triangulation technique and research results were presented by means of a descriptive analysis.

\section{RESULTS}

The research results revealed the following:
- In terms of the background of culture, beliefs and rite concerning deities of Buddhism and HinduBrahmanism in Bangkok and circumferences, it revealed that ancient-Thai society believed in deities and supernatural power which influenced by Hindu-Brahmanism and when Buddhism was diffused in Thailand and the Thai people accepted it as a main religion, they assimilated both HinduBrahmanism and Buddhism together so they worshiped both the deities of Hindu-Brahmanism and Buddhism; for example Bodhisattva, Genesha, Brahma and Vishnu. Bangkok and circumferences

- In terms of the current situations of the assimilation of culture, beliefs and rites concerning deities of Buddhism and Hindu-Brahmanism in Bangkok and circumferences, it reveals that people worship both the deities of Hindu-Brahmanism and Buddhism for receiving good luck, richness, happiness, good health, a success of work, a success of education, a success of love and others so a lot of deity images are built at the temples and abodes of gods in Bangkok and circumferences. This behavior becomes the culture of worshiping deities in Thai society. The problem is some people is infatuated with a blessing from deity, they believe that deity can give them everything, they lose their confidence in solving their problems and become the victims of gangsters who run wrongful business concerning the beliefs in deities

- In terms of a suitable assimilation model of culture, beliefs and rites concerning deities of Buddhism and Hindu-Brahmanism for peace of Thai society in Bangkok and circumferences, it reveals that a suitable assimilation model should consist of faith and wisdom by using beliefs and rites as the reinforcement of life and applying deity's virtue such as a virtue of do not make a sin throughout lifetime or a virtue of Hiri-Ottappa (moral shamemoral fear). This ideal needs monks to play a role of spiritual leaders, they ought to teach people to use their faith and wisdom for worshipping deities and to get the virtue of deities for leading their life to success. Moreover, both religious adherents of Buddhism and Hindu-Brahmanism ought to conduct themselves according to the virtue of deities and suggest other ones the suitable assimilation of culture, beliefs and rites concerning deities for peace and happiness

\section{DISCUSSION}

The results of the study were discussed as follow: 
- The background of culture, beliefs and rite concerning deities of Buddhism and HinduBrahmanism in Bangkok and circumferences began from the beliefs in animism and HinduBrahmanism of people because the social context of ancient-Thai society was compatible with the beliefs in animism and Hindu-Brahmanism which rooted in these areas before the diffusion of Buddhism. Thus, when Buddhism diffused in these areas as a main religion, people assimilated animism, Hindu-Brahmanism to Buddhism according to the social change. This is congruent with Bunkoet Laomi, Songkoon Chantachon and Niyom Wongphongkham (2009) who studied about "A model of Pulpit Conservation and Revitalization Using Community Participation of Phu-Thai People in Northeast Thailand”. The result of thesis reveals that the model and structure of the pulpits are from beliefs in village pillar spirits in harmony with faith in Buddhism. The pulpits are constructed for use in performing religious affairs as the architectural symbol. This can compare to the creation of deity images of Buddhism and Hindu-Brahmanism which also originates from religious beliefs.

- The current situations of the assimilation of culture, beliefs and rites concerning deities of Buddhism and Hindu-Brahmanism in Bangkok and circumferences reveals that at present, the relationship between the Indian people and Thai people get on together quite well. Both the Indian and Thai people sometimes practice their rites together. Moreover, some Buddhit monks or Buddhist leaders assimilate rites concerning deities of Buddhism to rites concerning deities of HinduBrahmanism as if they originate from the same beliefs. Several Buddhist temples located HinduBrahmanism deities concerning deities of both religions for people's buying. This is congruent with research result, he studied about "A Study of Cultural Assimilation of So and Northeast People : A Case Study of Tambon Kusuman and Tambon Photi Phaisan, Amphoe Kusuman, Changwat Sakon Nakhon. The result reveals that the success of cultural assimilation depends on close relationship of people in each society, this relationship proceeds slowly, it has no limits of time and patterns such as new comers who live in new society at initial term they encounter with disparagement of old comers and when they adapt themselves to this pressure and can defeat it finally, both new comers and old ones become close friends and get on together.
- A suitable assimilation model of culture, beliefs and rites concerning deities of Buddhism and Hindu-Brahmanism for peace of Thai society in Bangkok and circumferences reveals that it should consist of faith and wisdom by using beliefs and rites as the reinforcement of life and applying deity's virtue such as a virtue of do not make a sin throughout lifetime or a virtue of Hiri-Ottappa (moral shame-moral fear). The success of this assimilation needs monks to play a role of spiritual leaders, they ought to teach people to use their faith and wisdom for worshipping deities and to get the virtue of deities for leading their life to success. Moreover, both religious adherents (Buddhists and Brahmans) ought to conduct themselves according to the virtue of deities and suggest other ones the suitable assimilation of culture, beliefs and rites concerning deities for peace and happiness. This is congruent with research result of Phrakhrusutawisutthikun Phad, Wisanee Siltragool and Terdchai Panthachai (2010), he studied about "Suitable Management Model for Economic, Social and Cultural Development Derived from Beliefs and Rites on Pra Buddha Southern in Chachoengsao Province" The result reveals that an appropriate management model in developing the temple and community regarding to economic, social and cultural aspects would be a model for being applied in others temples with similar nature as well as a guideline in developing Wat Sotonwanaram

\section{CONCLUSION}

Research result reveals a suitable assimilation model of culture, beliefs and rites concerning deities of Buddhism and Hindu-Brahmanism for peace of Thai society in Bangkok and circumferences. This cultural assimilation is useful for social solidarity of Thai society and perhaps other societies that have their social context like this.

\section{ACKNOWLEDGEMENT}

This research was supported by the Research Institute Northeastern of Art and Culture, Mahasarakham University. The authors wish to express our sincere thanks to the Research Institute Northeastern of Art and Culture, Mahasarakham University, the people in 9 research areas and all of the support provided. 


\section{REFERENCE}

Laomi, B., S. Chantachon and N. Wongphongkham, 2009. A model of pulpit conservation and revitalization using community participation of Phu-Thai people in Northeast Thailand. J. Soc. Sci., 5: 374-376. DOI: 10.3844/jssp.2009.374.376

Phad, P., W. Siltragool and T. Panthachai, 2010. Suitable management model for economic, social and cultural development derived from beliefs and rites on prabuddha southern in Chachoengsao province. J. Soc. Sci., 6: 4-7. DOI: 10.3844/jssp.2010.4.7
Ratchathon, P.A., 1988. Cultural Section: An Anthology of Culture. 1st Edn., Silpakorn, Bangkok, ISBN: 9740007619, pp: 294.

Talang, A.N., 2001. Local Wisdom of Central Part Thailand. 1st Edn., Amarin Book Centre Company Ltd., Bangkok, ISBN: 9742723877, pp: 229. 